\title{
MINUTES OF THE GENERAL ASSEMBLY of the 2nd CONGRESS of the WORLD FEDERATION OF SOCIETIES FOR LASER MEDICINE AND SURGERY
}

\author{
held during Laser Tokyo 2009 in the Meiji Kinenkan, Tokyo, November 29th 2009
}

There being a Quorum, the meeting was opened and called to order by President-Elect Prof. Krishna Rau at 16:35, who then welcomed the current President, Prof. Kazuhiko Atsumi. Prof. Atsumi expressed great pleasure that so many friends and colleagues were in attendance, and welcomed everyone with the hope that they would all enjoy Tokyo. Prof. Atsumi then handed over the President's Medallion and Chain to Prof. Rau, who then became the official President of the WFSLMS for the next 4 years.

Prof. Rau thanked Prof. Atsumi for a very successful term as President, starting in Chennai, 2001, and proceeding through the $1^{\text {st }}$ WFSLMS meeting in Tokyo, 2005 to the present meeting. He then welcomed Prof. Atsumi into the Executive Committee as the Founding President. Prof. Rau also expressed gratitude on behalf of the Federation to Prof. Ohshiro for his tremendous support during this term, and of course as Congress President of Laser Tokyo 2009. The WFSLMS bylaws were then read and ratified. The 2009 WFSLMS Executive Committee was proposed and agreed as follows:

WFSLMS Executive Committee, 2009-2013

\author{
Honorary President \\ Founding President \\ President \\ President-Elect \\ Secretary-General \\ Assistant Secretary-General Narong Nimsakul (Thailand)
}

\author{
Honorary Treasurer \\ Branch Members
}

Vasant Oswal (UK)

Mary Dyson (Europe)

Sherif Awad (Africa)

Honorary International Abraham Baruchin (Israel)
Gu Ying (Asia-Pacific)

David Sliney (North America)

Fernando Soriano (South America)

Prof. Rau stated that the World Federation functioned as an umbrella Society, with the main aim of spreading laser use mainly to the developing countries, in some of which Profs Ohshiro and Nimsakul had already delivered lectures and run teaching courses, so the Federation had certainly started to achieve that aim.

Another major goal was the establishment of the new certification initiative for International Medical Laser Specialist (IMeLaS). On November $26^{\text {th }}$ and $27^{\text {th }}$ the first initiative course was held, and Prof. Rau called on Prof. Ohshiro for details. Prof. Ohshiro reported that 17 young medical doctors ( 6 from Thailand and 11 from Japan) had taken the course of didactic lectures being given on both days by R Glen Calderhead (UK \& Japan), Penny Smalley (USA) and Profs Ishiwatari (Japan) and Sliney (USA). On the morning of the $27^{\text {th }}$ Prof. Ohshiro oversaw a hands-on course with a variety of lasers at the Ohshiro Clinic, and after the didactic sessions in the afternoon the candidates sat a written multiple choice type examination. All candidates passed with an average score of around 67\%. Prof. Rau thanked Prof. Ohshiro for his hard work, and asked when the certificates would be handed out. Prof. Ohshiro replied that they would be awarded during a Tokyo Bay Cruise the following evening.

Prof. Rau then announced that the next courses would be held during the $201013^{\text {th }}$ APALMS Congress in Suwa City, Nagano, Japan, and the 2011 ISLSM congress in Seoul Korea, with the potential for other courses including Laser Florence in November 2010. He also announced that Prof. Leonardo Longo (Italy) had been tasked with charting out the IMeLaS academic course syllabus, to which Prof. Longo had agreed with a 6-month deadline having been set. During this time an information package would be prepared to be sent to young doctors to attract them to take the certification course. The course should have 2 components: a core laser knowledge syllabus for all participants followed by a more advanced speciality-specific course. Prof. Rau called for assistance for Prof. Longo, and especially for the speciality-specific course, WFSLMS members should rally round and help, which would be mutually beneficial both the IMeLaS initiative and the WFSLMS itself.

It was then announced that the $20^{\text {th }}$ ISLSM and the $3^{\text {rd }}$ WFSLMS would hold a joint meeting in 2013 in France, under the Presidency of Prof. Jean Abitbol (France), so that Prof. Abitbol's centre would become the nidus of all aspects of the laser in surgery and medicine. This was unanimously accepted. Prof. Abitbol was therefore the new President-elect. Prof. Rau asked everyone present to leave a note of their email address so two-way communication could be established. When asked how we should proceed during the next 4 years, Prof. Atsumi thanked Profs Ohshiro and Rau for organizing the current meeting, simply reinforced the idea that all present at the GA were in the project together, and that we should all therefore pull together and contribute what, and as much as, we could.

Prof. Rau then called on the 'Father of the CO2 Laser', Prof. Isaac Kaplan (Israel), to say a few words. In his usual inimitable and wonderful style, Prof. Kaplan expressed his feelings in Rhyme, which was warmly applauded. He concluded by pointing out that when he taught 'how to use the laser' it has always been a core knowledge course, and did not think that we really needed specialty-specific breakouts. Mrs. Masha Kaplan then congratulated all the organizers of the joint meeting, but had a special word of thanks to Prof. Ohshiro for having put the meeting together in less than one year, instead of the usual two years.

Prof. Leonardo Longo was then asked to contribute. Prof. Longo agreed that finalizing plans for certification could be very difficult, as different laws and regulations existed in different countries. This could lead to fragmentation. However, provided the concept of an international laser specialist certification, such as the IMeLaS initiative, was correctly presented, then that would help bridge problems to offer young doctors a good basic grounding in the core laser knowledge. He thanked the meeting for putting the responsibility on his shoulders, and avowed he would do his best.

Prof. Narong Nimsakul (Thailand) spoke next. He reminded everyone that the main aim of the World Federation was to bring laser societies together under the same umbrella, and although members should of course include doctors, dentists, veterinary surgeons and research scientists, we should never ever forget nursing and allied health workers, so he reminded everyone that they had established the International Society for Laser Nurses and Allied Health Workers at the ISLSM meeting in 1983. He then called on the current president, Penny Smalley (USA) for her comments. Ms. Smalley pointed out that the first international society for laser nurses was established in 1983 in Detroit. She reminded all present that nurses were specialists, and collaborative 
partners with the laser surgeon. It is the job of the nurse to protect the patient during laser surgery, Ms. Smalley said, and if she or he did not know the basics of laser science and tissue interaction, they would not be able to do that. She asked the meeting please to bear that in mind when thinking of who could participate in courses.

Ms. Smalley handed the meeting back to Prof. Nimsakul, who asked Prof. Jin Wang Kim (Korea), President-elect of the ISLSM and congress president of the $201119^{\text {th }}$ ISLSM meeting in Seoul, Korea, for a few words. Prof. Kim thanked Prof. Ohshiro for all his hard work in putting together such a superb congress in less than a year, and hoped that he would succeed as well. He asked for everyone's assistance, as the World Federation was the umbrella society for the ISLSM, and urged as many as possible to attend and bring friends and colleagues.

Prof. Yoshimi Asagai (Japan) was next asked to say a few words as the President of the $201013^{\text {th }}$ APALMS meeting in Suwa, Japan. Prof. Asagai said how honoured he was to have been entrusted with the meeting, which would be held from October $8^{\text {th }}-9^{\text {th }} 2010$. He pointed out that Suwa is in the centre of Japan, and only 2.5 hours by train from Tokyo, so everyone should please attend his meeting!

Prof. Abitbol then addressed the GA. He looked forward very much to the meeting in 2013, and thanked Profs Rau, Atsumi and Ohshiro for all of their work to date. He pointed out that it was much more important to identify the things which we could not do, rather than those we could. He also noted that one man could not possible handle everything alone, so he really expected teamwork from all involved. In 4 years' time there would be even greater technological advances, he added, so he needed help from everyone, worldwide.

Prof. Rau then called on Prof. Harubumi Kato, the President of the JSLSM, the host organization for Laser Tokyo 2009. After thanking and congratulating Profs Ohshiro and Rau for organizing what promised to be an excellent meeting, Prof. Kato stated that there was a fast-growing need worldwide for minimally invasive and high quality integrative medicine, so we therefore absolutely needed laser technology and surgical techniques to meet this need. He insisted that cooperation between laser societies in different countries was essential for this goal, so the WFSLMS had an absolutely pivotal role to play.

Prof. Vasant Oswal (UK), Treasurer of the Federation, spoke next. Prof. Oswal thanked Prof. Ohshiro for a really fantasticlooking Laser Tokyo 2009. He then announced that the European Laser Association was once again active with a great meeting planned for May in Tarragona, Spain, entitled Laser Europe 2010. This would bring together the British Medical Laser Association (BMLA), Spanish Medical Laser Association (the host organization) and the European Society for Laser Aesthetic Surgery (ESLAS) under the ELA banner, so please come. It would naturally be possible to run another IMeLaS course before or after this meeting, but now that the Federation had successfully run the first course in Japan other countries would follow suite. He asked if it was actually necessary for the WFSLMS to oversee every course, and wondered if courses could be run with the approval of the Federation, accredited by the Federation and with the WFSLMS logo on the certificates. Naturally there was a lot of work to formulate everything properly, Prof. Oswal added, and that had been laid on the shoulders of Prof. Longo. He pointed out that, in the case of the BMLA, they approved educational courses in the UK, and then reapproved the courses every three years to make sure that the latest core knowledge had been included.

Prof. Rau agreed that if all went well with Prof. Longo's team, we would have a much better idea for the approved syllabus in 6 months' time. Prof. Rau then noted that there were indeed many courses run by many societies. Following on from Prof. Oswal's suggestion, Prof. Rau agreed that such societies should be approached to affiliate their courses with the WFSLMS, and be granted the use of the WFSLMS logo to be used on their course literature and certificate of completion. Societies accepting this arrangement will be required to pay a nominal fee for the use of the logo. These societies would then forward their course materials to Prof. Longo for approval of the academic level of the contents. On the subject of courses, Prof. Abitbol put forward his course for affiliation with the WFSLMS, and further very kindly offered to reduce the cost of his course to WFSLMS and ISLSM members by US $\$ 200$, which was very gratefully noted.

Prof. Nimsakul then took the floor and agreed that we should consider Prof. Oswal's idea very carefully. For example, if Vietnam wanted such a course, it could well be run by the WFSLMS team. He added that in the next 5 years it was hoped to formulate an ASEAN charter which might well encompass pan-ASEAN certification. The WFSLMS should have an important role in that.

Prof. Longo took to the floor once again, insisting that the aim of the IMeLaS initiative was completely different from the courses which are run before almost any congress, and that IMeLaS courses must be much more substantial. They must have an initial basic course, the core laser knowledge, for young doctors, not experienced laser surgeons who are already set in their ways. This core knowledge course could then be followed some months later by a set of different speciality-specific courses They must be excellent courses, and he said that we had to change the quality of the teaching. The didactic part would be handled by the International Academy, and the entire concept must be a long-term consideration and not just one or two hours precongress.

Prof. Mary Dyson (UK) was then recognized. She expressed herself extremely impressed with all the suggestions, and with the progress that had already been made. Prof. Dyson suggested that we might consider putting some of the theory on the Internet so that courses which were difficult to get to could be avoided. She also wondered how best to test the practical skills of IMeLaS candidates, and said that only surgeons could do that. Above all, she did not want to see certificates as meaningless pieces of paper.

Prof. Rau made it clear that the current IMeLaS course was only a start, and simply looked at core knowledge. Even so, the didactic sessions were challenging backed up with an excellent handbook, coupled with a comprehensive hands-on, and the written multiple choice test was comprehensive and not so easy. In future iterations of the initiative, candidates would get the course handbook well before the course, with suggestions on which key texts to study so that the examination could be extended to involve long written answers, short written answers and the multiple choice section.

Prof. Vladimir Mikhailov (Russia) was next recognized. He agreed that the cooperative IMeLaS initiative between the WFSLMS and ISLSM was an excellent start which would only get stronger with the input from the International Academy and Prof Longo. He then suggested the initiative would take another giant step forward with recognition of IMeLaS certification by Ministries of Health worldwide. Whether the national government recognized the course or the course was presented to the government by the course organizers, it is vital to get international recognition at a governmental level.

Prof. Abitbol then took the floor again. He reiterated his idea that we must look at the initiative as a team concept, that the diploma we offer currently was excellent, but did not go far enough. He asked if there could be a proctorship element to the second part of a two-stage course, similar in concept to what Profs Longo and Dyson had already suggested. However, he agreed that we must start somewhere and the current core laser knowledge course was an excellent start.

Prof. Ohshiro then added that a government-approved system, similar to what had been suggested, already existed in Japan with a 4-grade award system: in addition to being a plastic surgeon, a physician then becomes a Laser Specialist in Plastic Surgery. However, some countries have no standards, so the IMeLaS initiative offers standards. In those countries where stan- 
dards already exist, then the IMeLaS initiative should be moulded to follow those standards. Prof. Mikhailov agreed completely with Prof. Ohshiro. If the government of one country were to give support to the IMeLaS initiative, other countries would follow. When no standards exist, then the IMeLaS standards would be an excellent starting point.

Prof. Oswal reminded everyone what Prof. Kaplan had said, that the laser was simply a tool and doctors should all be taught how to use that tool in a basic and safe way before even thinking about speciality-specific training. They should be taught first how 'to do' laser in general before being taught how 'to do' laser surgery. Prof. Oswal stated that he had run an intensive ENT course in the UK for 26 years with some excellent teaching tools. The participants got 20 questions before the course, and then the same 20 questions after the course: this way they know how much they had absorbed. He also wondered about CME credits for the current IMeLaS initiative.

It was then pointed out that pan-European certification was much simpler because of the Bologna Agreement. This would be equally the case if a pan-ASEAN accord could be reached.

Prof. Nimsakul then talked about disaster preparedness from the point of the need for many trained medical personnel. The IMeLaS course could be taken as basic requirements for surgeons in areas prone to catastrophic disasters, natural or otherwise. Then we could have medical teams who were laser cognizant, which would be a great step forward. That must also be a consideration of the WFSLMS goals.

Prof. Atsumi mentioned that some people will have questions and requests for education \& training system on WFSLMS, however everything has both sides, merit and demerit. He believed it had been difficult to start and would be more difficult to continue, and that we would be able to improve after our experience with the current system. He concluded that we were happy to have started and thanks were due for the great effort of Prof. Ohshiro.

Prof. Rau stated that we had had a most fruitful discussion, and that we could expect to hear from him for our greater participation in WFSLMS activities. Prof. Atsumi agreed, saying that greater effort to obtain high level laser surgery should be made at a global level. Prof. Rau thanked Profs Ohshiro and Atsumi again for all their efforts, and said how much he was looking forward to the next 4 years. After thanking everyone for coming and participating, Prof. Rau closed the meeting at 17:40.

Respectfully submitted,

Toshio Ohshiro MD PhD,

WFSLMS Secretary-General.

\title{
MINUTES OF THE GENERAL ASSEMBLY of the 18th CONGRESS of the INTERNATIONAL SOCIETY FOR LASER SURGERY AND MEDICINE
}

\author{
held during Laser Tokyo 2009 in the Hotel Grand Hills Ichigaya, Tokyo, November $30^{\text {th }} 2009$
}

With a Quorum being present, Prof. Toshio Ohshiro as President-Elect of the ISLSM called the General Assembly to order and opened proceedings at 12:20. The financial accounts having been presented and accepted at the Joint Business Meeting of the ISLSM and WFSLMS the previous day, Prof. Ohshiro proposed their acceptance again and this was seconded by Prof. Narong Nimsakul (Thailand). The changes to the Articles of Association and Bylaws had also been ratified by the Executive and Advisory Council members present at the Business Meeting the previous day, and acceptance was proposed by Prof. Isaac Kaplan (Israel) and seconded by Prof. Rau.

Prof. Ohshiro explained that under the revised Bylaws, the ISLSM would be run by the Council, consisting of the Honorary Presidents, the Executive (Office Bearers of the Society) assisted by the Advisory Council, consisting of the immediate past president and five other national representatives, to be selected by the Executive. The 2009 ISLSM Council was then presented to the Membership for approval, as follows:

ISLSM COUNCIL, 2009 - 2011

$\begin{array}{ll}\text { Honorary Presidents } & \begin{array}{l}\text { Isaac Kaplan (Israel) } \\ \text { Kazuhiko Atsumi (Japan) }\end{array} \\ \text { President } & \text { THE EXECUTIVE } \\ \text { President-Elect } & \text { Toshio Ohshiro (Japan) }\end{array}$

\author{
Secretary-General \\ Honorary Treasurer Sharon Rau (India) \\ THE ADVISORY COUNCIL
}

Past President

Leonardo Longo (Italy)

Other members to be nominated and confirmed by the Executive

There was some confusion about who should fill the post of Secretary-General, but that was cleared up with Prof. Abraham Baruchin (Israel) accepting the post. There was also some discussion about the meaning of 'President' and 'President-elect' which was cleared up by Prof. Kaplan. Under the original idea, he said, the President-Elect was usually the same person as the president of the following congress, in this case Prof. Jin Wang Kim from Korea, where the 2010 ISLSM congress will be held. Prof. Ohshiro was now the ISLSM President, and he will hold that post for the next two years. The Council as proposed was unanimously approved, and Prof. Ohshiro then became ISLSM President.

Future congresses were next on the Agenda. The 2011 ISLSM congress will be held in Seoul, Korea, under the presidency of Prof. Jin Wang Kim of Haelym University, Seoul. It was decided that the 2013 ISLSM congress, which would be held jointly with the WFSLMS, would be held in France under the Presidency of Prof. Jean Abitbol. The dates and location will be announced when confirmed.

Prof. Ohshiro then presented the proposed fee structure for the ISLSM as follows: annual membership (with journal) US 